\title{
Norway Massacre: Theatricalized Terror-Spectacles of Ideological Propaganda
}

\section{Mona Al-Shaikh}

PhD Candidate, Faculty of Arts, Cairo University, Egypt.

\begin{abstract}
Defeating Terrorism requires understanding its ideological motivations, propagandistic tools, and artistic innovations, especially if the committed terrorist attacks are in the form of performative performances of theatricalized terror-spectacles. White supremacist terrorists who adopt a neo-Nazi creed, a racist ideology, and a genocidal political agenda have excelled in their theatricalized innovations, transforming terrorism into an art. Their main goal is gaining publicity by sacrificing innocent lives. Publicity expedites publishing their manifestos, which propagate for their ideological beliefs, filled with hate and fears. Anders Breivik, the Norwegian white supremacist neo-Nazi terrorist who committed the 2011 Norway massacre, the worst atrocity in Norwegian history has become a role model for terrorists worldwide. His theatricalized terror-spectacles, which he produced and performed artistically for propagandizing his racist ideological believes, communicate huge ideological, cultural, ethical, and aesthetic impacts. This study analyzes the theatricalization of his ideological beliefs, by exploring his performances of terror-spectacles, and analyzing his terrorist attack as a performed propaganda by deed. The study conducts the analysis through the broad-spectrum approach of performance studies as an interdisciplinary field of research. The analysis concluded that terrorist attacks, performed and theatricalized as terror-spectacles, are alarming propagandistic unethical artistic tools, disseminating insidious ideological beliefs, requiring a deconstructionist performance analysis, to overcome its overwhelming ideological and psychological detrimental impacts.
\end{abstract}

Keywords: Ideology; Propaganda; Terrorism; Terror-Spectacles; Megaspectacles; Theatricalization; Performance; White Supremacism; Neo-Nazism. 


\section{Introduction}

Ideologies play a very important role in shaping individual and social identities. They form the basis of political, social, and economic theory and policy. Ideologies are central, as they are "a product of social activity", and an "indispensable feature" of political practice (Freeden, Sargent and Stears 7). Most ideologies can be "rich and positive as well as destructive or indifferent", and they are "at the heart of concrete political thinking as practised across the globe in myriad forms" (7). Ideologies can be generally defined as "action oriented ideas concerning human communities seeking to achieve public influence and control" (9).

Terry Eagleton asserted that ideology, as a term, has "a whole range of useful meanings", however "not all of which are compatible with each other" (Eagleton 1). Ideology for him has "different conceptual strands" and "divergent histories", which creates a variety of meanings. Eagleton reviewed some of the most commonly used meanings of ideology, which he does not necessarily adopt. These include "a body of ideas characteristic of a particular social group or class"; "false ideas which help to legitimate a dominant political power"; "systematically distorted communication"; "forms of thought motivated by social interests", or "identity thinking"; "socially necessary illusion"; and "action-oriented sets of beliefs" (Eagleton 1-2).

Several approaches can be adopted in analysing an ideology. Raymond Guess enumerates some of these approaches. Analysing Ideologies can take a "descriptive approach", a "functional approach", and a "pejorative", or a "critical" approach (Geuss 7-8,12). A descriptive approach is usually an attempt to describe or explain "certain features of or facts about human social groups" (5). This typically includes "the beliefs the members of the group hold, the concepts they use, the attitudes and psychological dispositions they exhibit, their motives, desires, values, predilections, works of art, religious rituals, gestures, etc." (5). This descriptive approach to ideology is "non-evaluative and non-judgmental" (5).

The functional approach differentiates between ideologies "in terms of their functional properties" and "the way the elements of ideology influence action" (Geuss 8). Thus, a set of concepts or beliefs that influence economic behavior significantly would be an "economic ideology" (8). A religious ideology would be "a set of beliefs and attitudes which significantly influences religious practices" (8). Accordingly, ideologies can be political, economic, social, socio-economic, socio-political, ethical, epistemological, or even sexual.

The pejorative or the critical approach has been mainly adopted by Marxist thinkers. Marxists have been concerned with ideology as an "illusion, distortion, and mystification", and as a "false consciousness" through the paradigm of "true and false cognition" (Eagleton 3-7). Raymond Guess explains that an ideology can be a false consciousness "because it incorporates beliefs which are false, or because it functions in a reprehensible way, or because it has tainted origin" (Geuss 21). This study is concerned with one of the disturbing socio-political, ideologies that can be considered a false consciousness. It is the ideology embraced by the global movement of white supremacist neo-Nazis, who adopt an extremist far-right fascist racist ideology. Their ideology is a false consciousness as "it incorporates beliefs which are false" (21), based on conspiracy theories, such as the "Great Replacement" and "white genocide" (Am and Weimann 138). "The Great Replacement" and "white genocide" conspiracy theories claim that there is an alleged process of "replacement of European White populations by non-white migrants" (139). White supremacists also believe in a "fringe philosophy" called "Accelerationism" ("White Supremacists Embrace 'Accelerationism"”). Accelerationism "is a sub-ideology which seeks to hasten the end of modern society, insomuch as it is irredeemably corrupt" (Am and Weimann 138). 
In addition to being based on conspiracy theories, the white supremacist neo-Nazi ideology also "functions in a reprehensible way" (Geuss 21). It demonstrates its belief in accelerationism by encouraging "racial conflict through terrorism", aiming at "a societal collapse" to build a "white ethnostate" ("White Supremacists Embrace 'Accelerationism"”). They also utilize racial violence, terrorism, defamation, and vilification as propaganda vehicles to propagate their hate messages, as will be revealed through the analysis of one of their most lethal terrorist attacks, the Norway massacre. Their ideology also has a "tainted origin", as it relies in its logic and methods on the Fascist Nazi ideology, and considers the revival of the racist and violent Nazi regime one of its most important goals. The white supremacist neo-Nazi ideology fulfils all the requirements to be dubbed as a "false consciousness", as it is "contaminated at root", and "genetically flawed" (Eagleton 43).

Thus, this study adopts the Marxist definition of ideology, as a false consciousness, according to Guess's three conditions of falseness. The selected ideology fulfils the three conditions, as it is based on false beliefs, functions reprehensibly, and has a "tainted origin" (Geuss 21). The far-right white-supremacist neo-Nazi ideology is a false consciousness, that is necessarily "involving what is cognitively defective or deficient, in being illusory, deceptive, partial, distorted or at any rate failing in some way to present a veridical picture of the social world" (McCarney).

Such false conscious ideologies are usually associated with condemnatory or derogatory connotations, because of the heated ideological conflicts, propagating ideological fears and hate, such as the fascist and racist ideologies, motivating and fuelling one of the greatest threats of our contemporary age, namely racially motivated terrorism. Ideologists, who adopt and propagate ideologies of a false consciousness, have very strong beliefs and emotions that engage them in ideological struggles. These ideological struggles are usually fought through different propaganda outlets. The produced propaganda, whether it is a propaganda by word or by deed, disguise in different literary, cultural, artistic, aesthetic, theatrical, and performative forms.

Ideologies "mutate, gently or radically, smoothly or through ruptures" (Freeden, Sargent and Stears 8). The Neo-Nazi white supremacist ideology mutates radically and aggressively, through ruptures. Neo-Nazis are engaged in an ideological struggle to revive Fascist Hitlerian Nazism. Neo-Nazism as a supremacist ideology claims superiority; sacrificing innocent lives, by committing terrorist attacks, to gain publicity, to facilitate disseminating their propaganda, and to spread their ideological fears and hate. However, there is no cause, belief system or any ideology, irrespective of how influential or strong, that justifies sacrificing innocent lives for propaganda or other purposes. A performance analysis of terrorist attacks performed by neo-Nazis and white supremacist terrorists can help in understanding how ideologies of a false consciousness in general, and the white supremacist neo-Nazi ideology in particular, can develop, propagate, and become an extremist lethal threat. Analyzing such performances of Neo-Nazi terror-spectacles, as theatricalized terrorism can be beneficial in understanding ideologically motivated terrorism.

This study sheds light on white supremacist terrorism, its ideological motivations, and its unethical theatrical innovation that gives it artistic and aesthetic dimensions that facilitate its propagation through different propaganda outlets. Ideological propaganda may take the form of literary, cultural, and performance productions, of an aesthetic or artistic value. The evaluation of these values of ideological propaganda cannot be dissociated from an evaluation of the ethics of their production, especially if they cause influential socio-political transformations, such as terrorist attacks performed in the form of terror-spectacles. 
Recently, Neo-Nazi white supremacist terrorism has become the greatest terrorism threat, as "attacks by neo-Nazis, white supremacists and other extreme-right types are growing more common" (Freilich, Chermak and Gruenewald 38). According to the Global Terrorism Database, of the University of Maryland, "roughly 60 percent" of the 65 terror-related incidents, that caused the death of 95 victims, in 2017, "were driven by racist, anti-Muslim, anti-Semitic, anti-government or other right-wing ideologies" (Reitman).

The increase is not only in America, but also global, especially in "Western democracies" (Savage, Goldman and Schmitt). The Washington Post analysis of Global Terrorism asserts, "In Europe ... deaths from extreme-right terrorism have surged since 2010" (Economist). Thus, concerns are escalating, "that there is a growing transnational white supremacist or alt-right movement" that is establishing itself worldwide. Their main goal is to "use terroristic violence to bring about the collapse of what (their) literature calls the "System" or "the government and other institutions that organize society" (Economist).

White supremacist terrorist organizations consider themselves as "neo-Nazis, with an eschatological viewpoint" (Bromwich). They strive for "a breakdown of society that will lead to a race war, after which they intend to construct a new society based on their political principles", inspired by their "virulently racist and anti-Semitic views" (Bromwich). They fetishize "violence" and believe in using "degeneracy to establish order in a depraved modern world" (Bromwich). They embrace an "accelerationist ideology", believing in the motto "there is no political solution" (Wilson). Neo-Nazi white supremacist terrorists believe that "acts of violence and terror are required in order to push liberal democracy towards collapse, preparing the way for white supremacists to seize power and institute an ethnostate" (Wilson).

\section{Review of Literature}

Scholars of terrorism have increasingly remarked on "the theatrical proficiency with which terrorists conducted their operations" (Am and Weimann 132). Brian Jenkins, the international terrorism expert, asserts, "Terrorism is theatre" (Jenkins 4). The same perspective is shared by Am and Weimann, who elaborate, saying, "modern terrorism can be understood in terms of the production requirements of theatrical engagements" (Am and Weimann 132). They enumerated the production efforts of terrorists, which tend to be of a performative quality, rather than an operational one. They clarify, "terrorists pay attention to script preparation, cast selection, sets, props, role-playing, and minute-by-minute stage management” (132).

Nevertheless, in studying terrorism, its ideological motivations, and its propagandistic tools, a deep artistic theatrical analysis of terrorist-attacks, as performances of real-life events, is still lacking. This is attributed to the deep grief these terrorist attacks cause, especially if they result in the killing of innocent civilian victims. One example of these terrorist attacks, which requires an artistic theatrical analysis, for deeper perception and understanding, is the Norway massacre, committed by the white supremacist, Anders Breivik, in 2011.

Several studies tackled the attack from different angles. Some of these focused on Breivik's social background, as an abused child, such as The Mother (2013), by Marit Christensen, analysing Breivik psychologically through reflecting on his social upbringing (Ravndal). The Mystery of the Lone Wolf Killer: Anders Behring Breivik and The Threat of Terror in Plain Sight (2015), by Unni Turrettini, is a social-psychology study, evaluating and analysing the threat of dormant lone-wolf terrorists (Turrettini vii). Anders Breivik And The Rise Of Islamophobia (2014), by social anthropologist Sindre Bangstad, is a discourse analysis of the Islamophobic rhetoric across Europe, which formulated Breivik's false consciousness and racist ideological beliefs (Bangstad xiii). A Norwegian Tragedy: Anders Behring Breivik and the Massacre on Utøya (2013), is a study of the hidden "dark online worlds", providing 
extremist sources, for radicalizing European youth, through violent video games and Islamophobic hatred (Borchgrevink 6). One of Us: The Story of Anders Breivik and the Massacre in Norway (2015), by Asne Seierstad, is a psychological study of violent extremism and right-wing activism (Seierstad 39). The Dynamics of a Terrorist Targeting Process: Anders B. Breivik and the 22 July Attacks in Norway (2016) is a hate study, setting Breivik in comparative perspective, comparing him to other terrorists, and analysing his terrorism from a criminal angle (Hemmingby and Bjørgo 82).

The above studies have been so far the most extensive and meticulous sources, giving scholarly detailed analysis of the chosen case study. However, none of these studies attempted to analyse Breiviks' massacre as theatricalised terrorism, borrowing the tools of theatre, to reinforce ideological agendas. Consequently, this study attempts to fill this analytical gap by analysing Breivik's Norway massacre, through an interdisciplinary approach, under the umbrella of performance studies. This interdisciplinary approach combines the ideological, propagandistic, and the theatrical analysis, to analyse the terrorist's massacre, as an artistic performance of political violence. The study attempts to underscore the artistic innovations applied to his several terror-spectacles, which makes his terrorist attack, a distinct megaspectacle of terror, as its artistic innovative performance, multiplied its psychologically traumatizing impacts.

Most of white supremacist terrorists take Nazi leaders as their role models, such as Heinrich Himmler ${ }^{1}$. Yet, their ideological and operational inspiration is Anders Behring Breivik, the white supremacist separatist who committed the Norway massacre in 2011, "the deadliest lone-actor terrorist attack in history" (Berger). Breivik is considered an innovative terrorist, and his "innovation" is not only ideological, but also "operational" (Berger). His status is iconic on the far right, being referred to as "Commander Breivik" or "Saint Breivik". Neo-Nazis consider him a "sacred man", a "visionary" (Bangstad 25). Far-right terrorists and "anti-immigrant extremists" consider him "prophetic" (Berger). White supremacist terrorists intentionally assert him, proudly, as their stimulus and reference.

White supremacist terrorists adopt Breivik's ideological beliefs. Most of the neo-Nazi terrorist attacks are "modeled in significant part on Breivik's strategy", and bear "the marks of his belief system" (Berger), explained in details in his lengthy manifesto. White supremacist ideologists and terrorists closely "follow Breivik's manifesto", as they consider him their "guiding force" (Berger). Breivik's "belief system" and "lethality" makes him a stimulus for global incidents of terrorism (Berger).

Multiculturalism, as a political practice, first emerged, as an "ideological solution" to cope with "ethnic diversity" (Citrin et al. 247). However, presently, the western multicultural identity has been under attack by the serious threat of White Supremacism, an extremist ideology, reinforcing Nazi beliefs, and practices, manifesting itself violently, through racially motivated terrorism. White supremacist terrorists victimize racial, religious, and ethnic minorities.

For many neo-Nazis, white supremacists, and far-right extremists, full commitment to anti-multiculturalism is described as "going full Breivik" (Berger). One of those white supremacist terrorists, who went "full Breivik" is the Australian Brendon Tarrant who committed the 2019 New Zealand Christchurch shootings ${ }^{2}$. Breivik's influence on global white supremacists, calls for analysing the unethical aesthetic artistic representation of his ideology, through a performance analysis of his theatricalized staged terror-spectacles, to evaluate his destructive influence on global multiculturalism, as a propagandist for the neo-Nazi white supremacist ideology. 


\section{Problem of Study}

This study is concerned with an intricate problem that has ideological, ethical, and artistic dimensions. The problem is white supremacist terrorism that is motivated by ideological beliefs, propagated unethically through terror-spectacles. Borrowing their artistic tools from theatre and performance arts, terrorists perform terror-spectacles, through which they propagate their ideological beliefs, to propagate their hate and fear as theatricalized terrorism. Defeating terrorism requires understanding its ideological motivations and propagandistic tools. It also requires analysing how the motivating ideology is illustrated through the terrorist attacks, especially if it is taking the form of terror-spectacles, performed artistically and theatrically, facilitating the propagation of the ideological motivations, through different propaganda mediums, motivating other terrorists to commit terrorist attacks.

White supremacist terrorists unethically victimize innocent civilians to propagate ideological fear and hate, for political ends. Breivik is a "political terrorist motivated by ideological hatreds" (Bangstad 90). He adopts an extremist lethal ideology that is considered by all intentions "fascist" (23). In court trial, he "endorsed a long line of Norwegian and European neo-Nazis who had been behind violence and terror since the 1980s" (6), and were engaged in racist murders specifically targeting Muslims (23). Breivik has his "own ideology" (93). Breivik's theatricalized terror required "long and systematic ideological preparation" in order to "dehumanize the victims" (47).

He was very keen on disseminating his ideological propaganda through his manifesto. The "underlying ideological logic expressed" in Breivik's manifesto "is clear and terrifying enough" (Bangstad 90). Shortly before committing his terrorist attack, he "uploaded on to the internet a 1,516-page document", adopting the "Islamophobic discourses in Europe and the USA during the past decade (between 2001 and 2011)" (23). His main aim from committing his attack is to have through his trial "a public platform to spread his message" (24). Breivik intended his attack as a "shock attack", in order to create an "ideological reference point" (91). He intended his terror-spectacles as "instruments for educating the European peoples about the ongoing political, social, and demographical development" (91). He intended his terrorist attack as "a revolutionary "cleansing' violence" (102). He imagines himself as leading an "ideological struggle" to "start a war in Europe" (20).

His ideological belief is "conspiratorial and apocalyptic" (Bangstad 160). He believes in a conspiracy theory of "a supposed 'Islamization"” of Europe (24). The ideological logic states, there is an "ongoing 'Islamization of Europe', which forms part of a constant 1,400-year war between Christendom and Islam", which will lead to "the impending establishment of a Eurabia dominated and governed by Muslims" (90). He believes "Islam and Islamization" is an "existential threat" (180). Even though Breivik executed his terrorist attack as a lone wolf, his ideological motivations are "far more widely shared, in Norway as in Europe and even the USA" (41).

Through the following performance analysis, this study attempts to show how Breivik committed his terrorist attack in the form of four theatrical performance of terror-spectacles. The analysis will explain how Breivik managed to propagate his ideological hate, to illustrate to his target audience, through terror-spectacles his ideological motivations as a white supremacist terrorist. It is an analysis of his ideological beliefs and how he performed and theatricalized them, to justify his terrorist attack, to gain publicity and support. 


\section{Performance Analysis}

On July $22^{\text {nd }}, 2011$, a huge number of Norwegians were struck and severely bereaved by an atrocity that was committed, unremorsefully, affecting them personally, physically and psychologically. Seventy-seven innocent Norwegians lost their lives, and a much greater number of Norwegians lost them as friends, relatives, and acquaintances. One of the most shocking elements of this atrocity, which took the shape of domestic terrorism, is that it happened in Norway, a country that is rarely ever associated with terrorism. Yet, a huge terrorist attack happened, re-situating the small northern European country on the global map of domestic and international terrorism.

A 950-kilo fertilizer van bomb was exploded, at the heart of Regjeringskvartalet in Oslo, the Government Headquarters, in the capital, by Breivik, the "Norwegian right-wing extremist from the affluent western part of Oslo" (Bangstad $\mathrm{x})^{3}$. He planned for this terrorist attack, and specifically this explosion to be a grand spectacle, to compete and excel that of 9/11. Breivik chose to explode the Government Headquarters, the most powerful group of buildings in the country, to exercise, what Foucault called, and Breivik believes to be, his "right to punish" (7), as a white Nordic Norwegian, and "a fighter for the "survival of the Nordic race" (Vergara). From his perspective, the Norwegian government deserved this punishment, for being multiculturalist, dominated by "social democrats" (Bangstad x). Breivik, as a racist neo-Nazi, opposes multiculturalism as an ideological political solution. His ideological logic states that social democrats, adopting multiculturalism, are traitors. Thus, choosing the government as a target for his terrorist attack is ideologically significant, as it conforms to his white supremacist ideological convictions and formation, which vilifies multiculturalism.

\section{Methodology}

Performance studies, as an interdisciplinary field of research, and as a methodology, is an effective analytical tool. Its broad spectrum has the inclusive capability of analysing not only cultural events, but also real-life events as performances. It can be very effective in analyzing violently horrific real-life events, such as terrorist attacks. Hence, this study has chosen performance studies as a methodology for having a better cultural, aesthetic, ethical, and ideological understanding of the 2011 Norway attacks.

The choice of performance studies as a methodology is because it also has the capacity to analyse performed acts as metaphorical performances as well as performatives ${ }^{4}$. Some terrorist attacks are performed as metaphorical performances, as a performance of the metaphor of purity, racial purity, ethnic cleansing, and political purges. Yet, terrorist attacks can also be performed as performatives, real and actual. The Norway Massacre is one of the terrorist attacks that are performed as both a performative and a metaphorical performance of theatricalized terrorism. Breivik's performance of terrorism exceeded the metaphorical to the literal. He passed the threshold of the performance of terrorism to reach a terroristic performativity, committing a massacre, with actual, tangible, exploded, severed, dismembered, mutilated, dead, and alive bodies, traumatized minds, damaged spirits, and bereaved souls.

Racist, supremacist, and fascist ideologists share ideological convictions that legitimize sacrificing other humans, of different races and cultures, based on an alleged inferiority, even if they are innocent. White supremacist terrorists, who have these ideological convictions, have chosen to make a ritual of killing innocents, based on this alleged conviction of the inferiority of the other races and cultures. Through this killing of innocents, Breivik tries to arouse the Aristotelian tragic pity and terror, making a terror-spectacle of their torture. Breivik used the tortured bodies, of his victims, as props in his theatricalized terrorism to produce terror, torture, and power spectacles, to parade his ability to terrorize, torture, and overpower. 
Breivik's neo-Nazi terroristic acts and rhetoric is to promote the white supremacist racist ideology that victimizes and vilifies immigrants, specifically Muslims, as minorities. Breivik imagines his ideological struggle as a "crusade" (Bangstad 115), that specifically targets multiculturalism as a belief, culture, theory, and practice in Norway, allowing Islam as a religion and culture to be integrated, and Muslims to be assimilated. Thus, this study also tries to analyse the terroristic performance of Breivik, as an exemplary spectacle of power, utilizing torture as a punishment, to establish political authority, by instilling terror, through the performative lens of performance studies, based on Michelle Foucault's theory of the theatre of terror.

\section{The Norway Massacre}

\section{Breivik's Megaspectacle of Terror}

Breivik performed and directed, or rather orchestrated an incredible spectacle of ideological punishment that spectacularized the punishment of Muslims, for being Muslims, and multiculturalists for embracing them. Muslims are being punished for believing in Islam, which is for him not a religion but an ideology. He believes that Islam is "by definition, a 'fascist, violent, discriminating and genocidal political ideology"' (Bangstad 117). Thus, his punishment is ideological in nature, as he decided to punish Muslims as believers in Islam, and multiculturalists as believers in religious tolerance.

Breivik's performed his ideological punishment as a complex megaspectacle of terror. It consists of four major divisions. These are the exhibition of the explosion, the scene of the massacre, the demonstration of the trial, and the display of the prison. He performed four different terrorizing performances within each of the four displays. These are in order of appearance: the meticulous planner and executer of calculated violence in the exhibition of the explosion; a cold-blooded punisher and mass-shooter in the scene of the massacre; a defiant neo-Nazi white supremacist ideologist and an emotional loyal believer in the Nordic race supremacy in the demonstration of the trial; and the victim of human rights violation and an unremorseful propagandist and terrorist in the show of the prison.

Yet, before analysing such a performance of terrorism, or analysing any terrorism as performance, or as an ideological punishment, it is crucial to warn against what is considered as a shocking value of the performative turn (Burke 42). This "shock value" should be put into consideration, when analysing through the performative thinking and seeing through the performative lens. Analysing violence and terrorism as performance is not only challenging, but also disturbing and almost scandalous, because "real blood flows", crossing the threshold of performance to performativity. Even though analysing violence or terrorism as a performance is "shocking", it can also be perceptive, penetrating, and as Burke clarifies "illuminating" (42), which is especially true "in the case of the terrorism of our time as much as - or even more than-in earlier riots or pogroms" (42).

Many scholars adopted the performative approach in analysing ideological violence. Pierre Bourdieu was the first as "his notion of "symbolic violence"" is "linked to the idea of performance" (Burke 41). Foucault described public execution as a "theatre of terror" (49). Riots in the American South and France were analysed as "drama" or "moral scenario," including "rites of violence", and "lynching" (Burke 37). Even the "possession of the nuns", by "devils", was appraised as a "spectacle", in "le theatre des possedees", by Michel de Certeau (37).

This analytical approach, analysing terrorist attacks, as performed performances, of theatricalized terror-spectacles, cannot be easily accepted, especially from the point of view of 
the victims. Yet, analysing violence or terrorism, as a performance of ideological punishment is crucial to understand how "calculated violence" is utilized and exercised in our contemporary "media-saturated society" (Bell 7). This owes to the fact that our contemporary society is a "society of the spectacle" (Debord), a society of "media spectacles" (Kellner, Media Spectacle), or rather a society of megaspectacles.

Performance analysis is crucially needed. Bell insists that analysing terrorism as performance is not "an insult to the memories of those who died" (7). On the contrary, looking through the performative lens would be essential to understand how global conflicts, politics, terrorism, violence, torture, persecution, ethnic cleansings, and occupations are all being played as megaspectacles on a metaphorical symbolic level. Breivik's megaspectacle of terror is one example of the performances of calculated ideological violence. The structuring of his megaspectacle reflects not only dedication and ritualization, but also a perfectionism of performance, meticulousness of calculation, and entrenched ideological beliefs. Breivik structured his megaspectacle into four major horrifying displays. However, the exhibition of the explosion and the massacre were only performed to serve the scene of the trial, where he propagated at length his ideological hate and fear, and the display of the prison was its sequel.

\section{Megaspectacles}

Major life events, of everyday life, are usually constructed by media, through spectacles, namely, media spectacles. The greater the event, the more the space and the time needed to cover its spectacularization, which requires either the production of a major spectacle, or the production of several minor ones, to create a grand spectacle. This grand spectacle is the "megaspectacle" (Kellner, Media Spectacle 93). Breivik chose to display his ideological punishment in the form of a megaspectacle. His choice is because megaspectacles have overarching powers as a propaganda vehicle, as it has media dominance. Megaspectacles can be exemplified by wars, such as "the Gulf War", "sensational murder cases", exemplified by the "O. J. Simpson trials", or "terrorist bombings", exemplified by the September 11 attacks (Kellner, Media Spectacle 92).

Unlike a standard media spectacle, a megaspectacle has an all-encompassing power, as it has the capacity to "fixate attention on events that distract people from the pressing issues of their everyday lives" (Kellner, Media Spectacle 92). Megaspectacles are so penetrating to the extent that they can "define entire periods of culture and politics", bringing the entire "TV day to a halt", producing an "ongoing megaspectacle" (92). Regular programming is suspended to cover the events, and "the megaspectacle is discussed endlessly in talk shows on television and radio, on the Internet, and in conversations of everyday life" (92).

Breivik's theatre of terror has all the major elements that qualify it to be categorized as one of the major successful megaspectacles in the twenty-first century. It consists of several media spectacles; the spectacle of the rising action through the explosion, the shooting spree sets the island of Utøya, as a city of punishment, and a dramatic performance that was full of courtroom anxiety, in his trial. It is a megaspectacle that defined a period in Norwegian history. It halted all other coverage and pervaded every media outlet for a very long period of time, creating heated political and social controversies in Norway, America, Europe, and worldwide. A huge orchestrated production that took nine years of ideological and operational preparation and according to Breivik's own estimation, required over " $€ 30,000(£ 26,462)$ for armour and weapons, $€ 100,000$ for explosive materials, $€ 20,000$ for "logistics/transport/lodging" and " $€ 140,000$ for the creation of the compendium" (Taylor). The compendium is a manifesto disseminated electronically before the attacks to propagate his ideology, motivation, and inspiration, entitled 2083: A European Declaration of Independence. Breivik aspired for a 
major megaspectacle that would compete with and even excel the attacks of September 11, evident in his very first exhibition designed for the destruction of the Government Headquarters in the capital, Oslo, in the spectacle of the explosion.

\section{The Spectacle of the Explosion}

Breivik meticulously prepared for this explosion, to be a scene of collective ideological punishment for multiculturalists. The explosion "killed eight people, office workers and passers-by between the ages of twenty and sixty-one; nine others were severely injured, and another two hundred people received less severe injuries" (Bangstad 1). It was a severe explosion that "could be heard several kilometres away", leaving "the twenty-storey Government Headquarters" in total ruins, as well as the "neighbouring shops and buildings" (1). Breivik afterwards fled the scene, armed and "dressed in a fake police uniform", "complete with helmet and bulletproof vest," shown on "surveillance footage", (1).

Even though Breivik's explosion struck the heart of power, or to use Foucault's terms, the "centre of power", "in the centre of the city" (Foucault 307), horrifying and terrorizing, killing and mutilating, severing and dismembering body parts, he was not satisfied. Apparently, he saw that the government deserved a severer ideological punishment, for adopting a multicultural ideology, or he deserved greater acknowledgement, of his ability to punish and terrorize. This feeling is evident in his expression of "disappointment", after realizing that his "bomb had failed to make any buildings in and around Government Headquarters fall to the ground" (Bangstad 5). It is a "disappointment" caused by "reasoning that only a limited number of people rather than the hundreds he had hoped for had been killed there" (5). Dissatisfied that his imagined Foucauldian "city of punishment" was not fully materialized, he resorted to executing "his original plan B", "namely the attack at Utøya" (5), to make it the island of absolute and utter punishment. His choice of the island is ideologically significant as his choice of the government headquarters. The island is considered the centre of multiculturalism where multiculturalist political activists gather for their annual political camps.

\section{The Spectacle of the Massacre}

Securing publicity has always been Breivik's ultimate goal; as the greater the publicity, the greater his chances are for propagating his ideological hate. Kellner enumerated the types of events that can be "orchestrated", as "media spectacles" beside "terrorism", to secure the greatest possible publicity. Among those are "mass-shootings", as a "form of domestic terrorism", running "on live TV" (4). Breivik was keen on orchestrating the media spectacle of his massacre, in the form of a shooting spree, adequately, to have the widest possible media coverage. Thus, before he started the mass-shooting, he called the police, confessing that he is the perpetrator of the government headquarters explosion, informing the authorities that he is heading towards the island of Utøya. Thus, he started executing the massacre, and by the time, the police and the media were there, he was securing the publicity he has always dreamt of, by being filmed and photographed, amidst the execution of the massacre, propagating his ideological beliefs.

Breivik was not only successful in securing publicity but also in creating a state of terror. The torture-spectacles produced of his mass murder were instrumental in maintaining a state of terror throughout Europe. The sight of the spectacles of the mutilated, shot, and dead bodies of his victims during and after being massacred would reinforce his message. He used his victim bodies, in an illustration of torture and mutilation, during and after the attacks, as warnings, to both western multiculturalists and Muslim immigrants, that his threat is real and serious, unless they acquiesce to his demands of a massive ethnic racial cleansings, and ideological and political purgation. 
His choice of the island of Utøya, as an island of ideological punishment for Norwegians who believe in multiculturalism and co-existence was purposeful, as the island was hosting the Labour Party Youth Organization (AUF), which was holding its "annual political camp" (Bangstad 1). Breivik perceived the AUF members as legitimate "terror targets", as they were "social democrats", and have the "highest number of party youth activists with a minority background of any youth party organization in Norway" (9). Subsequently, "a number of the victims were of minority background" (8). Thus, the ideological punishment for believing in multiculturalism and Islam would be a collective punishment covering the greatest number of multicultural political activists as well as immigrants.

The shooting spree killed " 69 people between the ages of 13 and 51 - most between 15 and 19 - of the 564 people on the island - were killed, 67 by shots to the head and two plunging to their deaths or drowning while trying to escape" (Bangstad 18-19). Yet, those who were "maimed and scarred for life" were much more (Bangstad 1). According to prosecutors, the total number of affected people is nearly 900 people, in the explosion and the massacre, "325 in Oslo and 564 on Utøya" ("Norway's Mass Killer Breivik Declared Sane").

Breivik performed the role of a police officer coming to the rescue after news of the explosion spread. He patrolled the island, "calmly, systematically and without haste", "calling teenagers" to gather around him. He would then shoot them "at point-blank range", and "laughing loudly afterwards", appearing to be "in an elated state" (Bangstad 1). The images produced from the massacre scene, whether of Breivik shooting, or the victims escaping and jumping into the sea, or images of those who were shot dead or injured, carried on stretches, have indeed recreated Foucault's "theatre of terror", re-establishing the "city of punishment". It was a "ceremony of punishment", spectacled as an "exercise of terror" (49). Utøya became an island of ideological punishment, where the racially pure white Nordic supremacist exercised his "emphatic affirmation of power," and his "intrinsic superiority" (49). Hence, in line with Foucault's theory, Breivik proved his "sovereignty" and "superiority" (49). The proven "superiority is not simply that of right", his inherited genetic right, as a racially pure Nordic, but also of strength. His show of "physical strength", "beating down upon the body of his adversary and mastering it", seizing "upon the body of the condemned man", and displaying it, "marked, beaten", and "broken" (49). Thus, through a "policy of terror" (49), Breivik's ideology was disseminated, making everyone aware, through the bodies of his condemned, "the unrestrained presence of the sovereign" (49), the white supremacist "sovereign", the racially pure Nordic white "sovereign".

Consequently, Breivik's explosion and massacre, performed as a "public execution did not re-establish justice; it reactivated power" (Foucault 49). It is an ideological overpowering. It reactivated the ideological power of the white over the ideologies of multiculturalists and Muslims. Breivik executed his "punishment" in the same style of the seventeenth century punishments, described by Foucault, a punishment that "is carried out in such a way as to give a spectacle not of measure, but of imbalance and excess" (49). It has been a "liturgy of punishment", a "liturgy of torture and execution" that must "deploy its pomp in public" (49). The pomp of Breivik's punishment that is embodied in "its ruthlessness, its spectacle, its physical violence, its unbalanced play of forces, its meticulous ceremonial, its entire apparatus" are all "inscribed in the political functioning" (Foucault 49) of maintaining power in the hands of the white race, through the reinforcement of the white supremacist ideology. Breivik's "public execution" then is to be understood as a "political ritual", belonging to "ceremonies by which power is manifested" (47). Yet, that was just the beginning of the Breivik's megaspectacle of terror, as the climax was saved for the spectacle of the trial. 


\section{The Spectacle of the Trial}

After the exhibition of the explosion and the scene of the massacre, Breivik, as he previously planned, enters confidently and performatively into his third spectacle, the demonstration of the trial. In his Discipline and Punish, Foucault described "trials" as the ideal "exercise of disciplinary power" (198), where "rights and laws" should "function according to pure theory" (199). For this "jurists" should "place themselves in imagination in the state of nature; in order to see perfect disciplines functioning" (199). It was the responsibility of the court "to judge," and "to establish the truth of crime, it was to determine its author and to apply a legal punishment" (Foucault 19), to establish justice.

Yet, to see "perfect disciplines functioning", the "criminal's soul" must also be brought into questioning (Foucault 18). According to Foucault's theory the criminal's soul is not referred to in the trial merely to explain his crime and as a factor in the juridical apportioning of responsibility...it is because it too, as well as the crime itself, is to be judged and to share in the punishment" (18). Thus, it is not only crime that is being judged, but also "the 'soul' of the criminal" (19). Breivik, indeed, has a troubled soul. Thus, as challenging as the previous questions are, another question had to be brought up, the "question of madness" (Foucault 19).

Breivik insisted that "he is mentally stable" ("Norway's Mass Killer Breivik Declared Sane"), contending his sanity even though this means that if he "is deemed to have been sane at the time of the killings then he could face 21 years in prison with the potential for indefinite extensions to his term as long as he is considered a danger to the public" ("Norway's Mass Killer Breivik Declared Sane"). Yet, Breivik has very good reasons for contending his sanity, which has to do with how the "question of madness has evolved in penal practice" (Foucault 19), as "there is neither crime nor offence if the offender was of unsound mind at the time of the act". Thus, "the gravity of the act was not altered by the fact that its author was insane, nor the punishment is reduced as a consequence; the crime itself disappeared" (20). Hence, if Breivik is declared "legally insane", it would mean that all what he has done has "disappeared" (20). This loss means that all his imaginations, twice-behaved behaviours, planning, ideological preparations, executed efforts, rehearsed performance, and hard labour to set the scene of his major megaspectacle of terror, which lasted for nine years have failed, "meaning he would most likely be detained in psychiatric care" ("Norway's Mass Killer Breivik Declared Sane"). Subsequently, he did not accept his first psychiatric "assessment that concluded he was psychotic at the time of the attacks and diagnosed him as a paranoid schizophrenic" ("Norway's Mass Killer Breivik Declared Sane"). Thus, when the "second psychiatric evaluation...found him sane enough to face trial and a jail term", as he was not psychotic, but diagnosed as having a narcissistic personality disorder, he "was "pleased" with the new assessment" ("Norway's Mass Killer Breivik Declared Sane").

Breivik's pleasure is a result of his confidence that such a decision would allow him to further propagate his radical right-wing extremist neo-Nazi white supremacist ideological propaganda publicly and officially, within the sanctity of the courtroom, not only as a political terrorist, but also as an intellectual ideologist and propagandist. Facing trial means he would continue orchestrating his megaspectacle of terror, in front of the courtroom cameras, serving his racist agenda and narcissistic inclinations. This would allow him to continue his ideological struggle, or what he called a "crusade", "against multiculturalism and Islam" ("Norway's Mass Killer Breivik Declared Sane"). From that time on, he would continue to "defend his actions", the atrocious nature of which, he is aware. Unfortunately, being declared as "legally sane" contributed to the ongoing success of his megaspectacle of terror and gave it an intellectual edge. 
Breivik considered his legal sanity a triumph, as he never considered himself insane or even a terrorist, but a "political activist" with an ideological agenda, expressing, sending "a political activist to an asylum is more sadistic and more evil than killing him!", it would be a "fate worse than death" ("Norway's Mass Killer Breivik Declared Sane"). This triumph left him with only one "regret", which is that "he didn't go further" with his attacks, as his lawyer expressed. From that time on, the scene is set for the spectacle of the trial to start.

\section{The Trial as a Spectacle}

Since the start of the nineteenth century, the "advantage" of turning "trials" into an "occasion for political debate" or ideological expositions has been taken away from "controversial trials or proceedings" (Foucault 288). Thus, "the courts" were no longer "as they once were a place" for "exhibition"; "it is an arena that echoes with the cry of combatants" (288). However, trials in our contemporary age do not only have this "advantage" of spectacularizing "exhibitions", but this advantage has been exploited to the extent that criminals and mass murderers, such as Breivik, target victims and kill them specifically to get the opportunity for publicity.

Kellner asserts that in our contemporary age, in our society of mega-media spectacles, the law itself is subject to "mediatization" (Kellner, Media Spectacle 109). Participants in "highprofile trials" become "media celebrities" and use the media to "advance their positions" (109). Using the media is what Breivik took advantage of, orchestrating the media, becoming a master of his mega-media spectacle of terror. To orchestrate the media spectacle and be in control of its details, he consistently sent "open letters", "from his prison cell", to "media outlets", expressing his ideological beliefs, "supportive of the racist and discriminatory apartheid" practices and beliefs, describing figures such as "Nelson Mandela" as "terror leaders" (Bangstad 5).

Breivik created a courtroom spectacle and exploited its mediatization advantage after having planned for it for years. Breivik "had wanted to be captured alive in order to be able to lead his ideological struggle by telling the world about his reasons for wanting to start a war in Europe" (Bangstad 2). He "envisioned his trial as a public platform to spread his message" (6). In fact, his electronically published manifesto "contained a draft speech prepared for the trial". It is a speech that he "would eventually read at his first court appearance" (6). He murdered his victims to be a star of a media spectacle. It was not only his "ideological hate" (Berger), "intense hatred of both social democrats and Muslims" and multiculturalists (Bangstad 2) that led him to murder them. He murdered them as a means to an end. His end was and still is to create an ongoing megaspectacle, to spectacularize his deeds and "extreme right-wing views" (2).

In court, he would describe the acts of terror perpetrated on $22 / 7$ as 'fireworks' for the digital launch of his ideological tract 2083: A European Declaration of Independence. In his tract, he cites the need to instigate a civil war in Europe in order to stop the 'Islamization of Europe' by European Muslims and to halt the enablers of said 'Islamization' in the form of 'cultural Marxists' (Bangstad 8). Breivik showed "no remorse at his trial for killing 77 people" (Fouche). This was evident, as he "was at his most excited when describing the planning and execution of the attacks in all their dreadful details" (Bangstad 5). He was "able to recollect each and every murder in detail" (5). Breivik "never expressed any feelings of remorse for his actions", on the contrary, "he echoed German SS chief Heinrich Himmler's statements about the massacre of European Jews... in the course of WWII, when he described his actions as 'cruel, but necessary'" (5). 
Breivik exposed his ideological propaganda, in court, not only in words, but also in deed, physically as well as verbally. Defiantly, dramatically, and ritualistically, he performed his loyalty to the Nazi ideology every time he entered the courtroom, raising his hands and performing his Nazi salute, in the most dramatic solemn serious performance possible. His performance within the courtroom had a theatrical quality. He would start with the Nazi salute, and end up with an emotional gush of tears. He started weeping during the exposition of his terror manifesto, in which he declares his motives and ultimate goal of the total eradication of Muslims from Europe. He did not show any "compassion for his victims, saying in court that he would do it all over again if he had the chance" (Fouche). It was a trial where he performed the role of a defiant believer in the supremacy of the white race, as a white separatist. It is a supremacy he believes should be established through Nazi and Fascist practices to supress and exclude multiculturalists and Muslims whom he considers as the ultimate threat that should be alienated, if not exterminated, demanding a "territory for white in Norway", to strengthen the "survival of the Nordic race" (Vergara).

The verdict concluded, "Breivik adhered to an ideology which to all intents and purposes was fascist" (Bangstad 6). He confessed to this, declaring his ultimate goal to be creating a fascist party, through which his neo-Nazi Facist Islamophobic ideology can be practiced, confessing that his real drive for the terrorist attacks and atrocities is solely to gain publicity for his manifesto (Fouche). He explained that in his manifesto he used a "counterjihadistic" rhetoric, to support ethno-nationalists, to defeat Islam and Muslims and revive nationalism, lamenting the defeat of nationalists in the European Civil War (World War II).

\section{The Spectacle of the Prison}

The spectacle finale is Breivik's show of the prison. Prison, which Foucault explained to be the "penalty of civilized societies" (231), represents the application of the "power to punish", which is defined as "a general function of society that was exercised in the same manner over all its members, and in which each individual was equally represented" (231). This particular type of power must have a "justice" that is "equal", a "legal machinery" that is "autonomous". Yet, it must also contain "all the asymmetries of disciplinary subjection" (232) that should be variably suited according to each crime and each criminal. Thus, prison must provide punishments that are "not only graduated in intensity, but diversified in its ends" (233). Subsequently, an "individual condemned to light penalties", cannot be "imprisoned in the same place as the criminal condemned to more serious penalties" (233). Breivik's crime has been the most atrocious in Norwegian history. Thus, he was sentenced to solitary confinement, for the severity of his act, to prevent him from further disseminating his poisonous ideology, as well as to protect him from retaliatory attacks from other inmates.

One very important character of the prison is that it is "an apparatus for transforming individuals" (Foucault 233), through "deprivation of liberty" (232-233). It has a "corrective task", for "reforming individuals" (233). Thus, the function of the prison is simple, namely, "the deprivation of liberty and the technical transformation of individuals" (233). This transformation is executed through "levying on the time of the prisoner", as this deprivation should make the prisoner aware that the committed offence "has injured, beyond the victim, the society as a whole" (232). Thus, the function of the prison is "the amendment of the guilty man", it is a "transformation" that "must be one of the internal effects of imprisonment" (234). Thus, by depriving the prisoners of their external liberty, they should be transformed internally. However, this is not the case with Breivik's imprisonment. He continues to propagate for his hate ideology behind bars. His correspondences with media outlets have shown an unrepentance and a determination to continue his ideological "crusade" against "social democrats" and "Muslims" (Hanley). 
As a performer of a great terroristic performance, Breivik wants to guarantee having a continuous audience, so that the megaspectacle would continue running. Hence, being keen on continuously and consistently attracting media attention, he "threatens hunger strike" ("Norway killer Anders Breivik Threatens Hunger Strike"). He threatens, "to starve himself to death in protest at his treatment in prison". He claims that being "kept in isolation", with "time outside his cell limited to an hour a day" is a human-rights violation. Orchestrating his ongoing media spectacle, he sends letters to media outlets in Norway and Sweden, claiming that his "prison conditions" are "inhumane" ("Anders Behring Breivik's Prison Conditions 'Inhumane"'). Breivik being an "inmate", he has a "right to higher education", he had the right to be admitted to the University of Oslo. However, his "deteriorating prison condition" forced him to "drop out of a political science course", as "researching and corresponding is not humanly possible under such circumstances" ("Norway killer Anders Breivik Threatens Hunger Strike"), even if he continues playing "video games, watch TV and exercise" (Hanley).

Yet, Breivik's main grievance is that he is "not allowed to receive letters from sympathisers", and has been "prevented from sending letters to people such as the Aryan Brotherhood $^{5}$ in the US and a jailed Russian neo-Nazi" ("Anders Breivik: Just How Cushy Are Norwegian Prisons?"), which he considers a violation of his "right to "correspondence"" (Hanley).This violation would hinder him from continuing his "ideological struggle", "crusade", his counter-jihad crusade, against "social democrats", multiculturalists and "Muslims". As a result, Breivik defiantly, goes back in court, and appeals against these "human rights violations". Determined and unrepentant, Breivik still orchestrates his megaspectacle of terror, by manipulating the legal system and the media, behind bars.

Foucault enumerated the questions that should be answered in prison punishment. These questions are "How can we assign the causal process that produced it? Where did it originate in the author himself? Instinct, unconscious, environment, heredity? What would be the most appropriate measures to take?" (19). Unfortunately, none of these questions were answered. It is true that Breivik's "radicalization" was through "the 'echo chambers' of extreme right-wing milieus online" (4). Yet these "echo chambers' were not of" Breivik's "own making" (3-4). It is symptomatic of an ideological global problem of white supremacist racism. Bangstad admits, "Breivik's extreme acts may have much to do with his troubled personal background and mental problems" (3), warning against being trapped in the story of the narcissistic Breivik, as it is merely a minor detail in a much bigger picture. However, trapping his spectators is exactly what Breivik has been very successful in doing, inspiring white supremacist terrorists to follow his lead, to go "full Breivik".

\section{Conclusion}

Ideologies have various definitions and meanings. Descriptively, they can be representative of certain social groups. Functionally, they can be used as a tool to legitimate a dominant political regime. Through propaganda, ideologies can disseminate beliefs and reinforce the social interests of specific social groups. They can also shape identities through a set of beliefs that are action-oriented. As much as ideologies can be enriching and constructive, they can be oppressive and destructive. One example of such oppressive and destructive ideologies is the fascist far-right extremist ideology of white supremacist neo-Nazis.

In analyzing such a disturbing ideology, the Marxist approach, which is concerned with ideology, as a "false consciousness", has been adopted. Through this approach, the study analyzes the selected ideology as false beliefs, of a tainted origin that employs a reprehensible destructive propaganda machine that uses terrorist attacks as a propaganda outlet. Their 
terroristic propaganda outlet is mainly concerned with disseminating baseless racist conspiracy theories.

One of their most successful terrorist attacks, through which they were most successful in propagating their hate messages, is the 2011 Norway massacre. Anders Breivik the perpetrator of the massacre declared that his main motive for committing the massacre is the revival of the racist fascist Nazi regime. He considers himself engaged in an ideological struggle, or rather a crusade.

The proficiency of his terrorist attacks performed as terror-spectacles of a theatrical artistic performance calls for analysing his terrorist attack as a megaspectacle, under the umbrella of performance studies. Such an analysis can be helpful in understanding ideologically motivated terrorism, and consequently, in defeating it through social and political awareness. It can also help in overcoming its psychologically detrimental impacts, multiplied by the unethical utilization of the artistic tools of theatrical performance. Understanding such theatricalized terrorism can also help in resisting and reversing the violent socio-political transformations it causes.

White supremacist terrorists have become increasingly efficient in the theatricalization of their terrorism. In his four major terror-spectacles, Breivik paid his utmost attention to script preparation, as his manifesto included a statement to be read aloud in court. He rehearsed his role-playing, as he had several roles to play through his megaspectacle, such as the role of the police officer coming to rescue, as well as the defiant Nazi believer in court. He was able to manage his trial stage, through his knowledge of court hearings routines. Hence, Breivik has become an operational and ideological inspiration. This is attributed to his successful planning and execution of a great theatre of terror, in the Foucauldian sense, where he exercised the white sovereign abilities to punish Muslims for immigrating to Norway, and to punish the government for allowing this immigration. His punishment is an ideological one, applying a "counter-jihadistic" rhetoric, as he is trying to prove his superiority in face of the social democrats, and Muslims, who adopt a non-racial ideology, namely multiculturalism.

White nationalist supremacist and separatist terrorists, such as Breivik, might appear as classic "lone wolves", but they are part of "a global threat and a terrifying trend" (Economist). They are usually "not part of any organization". They develop and propagate their ideological propaganda, spreading fear, hate and "violent beliefs" on their own, "surfing the internet", buying their own weapons and training alone, so no one would suspect they are "preparing a massacre" (Economist). They believe in myths repeated "in social-media posts" and "speeches of elected politicians from Hungary to Iowa" (Economist), such as the "The Great Replacement", conspiracy theory, which states, "non-white and Muslim immigrants in Western countries are invaders, ushered in by scheming elites to replace ethnic-European populations" (Economist).

These propagated ideological misbeliefs are of an unprecedented danger as they are being increasingly endorsed, not just by terrorists, but also politicians. Breivik's ideological and cultural influence can be traced in propaganda productions produced by western terrorists, such as the 2019 New Zealand tragedy. Thus, there has been a global "significant increase in racially motivated violent extremism" (Wilson), due to Breivik's successful propaganda by deed. This increase in white supremacist terrorism is indicative of the dangers of white supremacist ideological propaganda, and how these propaganda productions, by neo-Nazis, as Breivik are affecting global multiculturalism, threatening the peaceful co-existence within culturally diverse societies. Thus, awareness against such theatricalized terrorism, performed as neo-Nazi attacks against global multiculturalism, must be created to prevent its fatal effects. 


\section{Notes}

${ }^{1}$ Himmler was the commander of the Schutzstaffel (SS), the Nazi organization responsible for genocidal killings during WWII.

${ }^{2}$ It is a massacre committed by an Australian white supremacist, killing and injuring 100 Muslim worshippers while praying within their mosque, streaming the killings on Facebook Live.

${ }^{3}$ Sindre Bangstad is a Norwegian social anthropologist. He worked as an associate professor at Oslo University.

4 "Performative" or "performativity" is a term used in performance studies and the performance arts, to evaluate the performance of performers according to the degree of its reality, actuality, or sincerity. The term performativity denotes "the capacity to execute an action, to carry something out actually and thoroughly, as well as to do according to prescribed ritual" (Berns).The more the performers believe their role within the performance, performing sincerely, and the more their actions are actualized and ritualized, the more performative is their performance, achieving performativity.

5 The American Aryan Brotherhood is the "oldest major white supremacist prison gang and a national crime syndicate" in the U.S. (SPLC).

\section{Works Cited}

Am, Ari Ben and Gabriel Weimann. "Fabricated Martyrs: The Warrior-Saint Icons of FarRight Terrorism." Perspectives on Terrorism (2020): 130-147.

"Anders Behring Breivik's Prison Conditions 'Inhumane'." BBC NEWS 9 November 2012.

"Anders Breivik: Just How Cushy Are Norwegian Prisons?" BBC NEWS 16 March 2016.

Bangstad, Sindre. Anders Breivik and the Rise of Islamophobia. London : Zed Books , 2014.

Bell, John. "Performance Studies in an Age of Terror." TDR (2003): 6-8.

Berger, J M. "The Dangerous Spread of Extremist Manifestos: By sharing the writings of terrorists, media outlets can amplify their impact." The Atlantic 26 February 2019.

Berns, Ute. "Performativity." 19 December 2012. The Living Handbook of Narratology. 5 January 2019.

Borchgrevink, Aage. A Norwegian Tragedy: Anders Behring Breivik and the Massacre on Utøya (2013) . Cambridge: Polity Press, 2013.

Bromwich, Jonah. "What Is Atomwaffen? A Neo-Nazi Group, Linked to Multiple Murders." The New York Times 12 February 2018: https://www.nytimes.com/2018/02/12/us/what-is-atomwaffen.html.

Burke, Peter. "Performing History: The Importance of Occasions." Rethinking History (2005): 35-52.

Citrin, Jack, et al. "Multiculturalism in American Public Opinion." British Journal of Political Science (2001): 247-275.

Debord, Guy. The Society of the Spectacle. Trans. Ken Knabb . Canberra: Hobgoblin Press, 2002.

Eagleton, Terry. Ideology: Introduction. London: Verso, 1991. 
Economist, The. "Far right and very wrong: Why white nationalist terrorism is a global threat." The Economist (2019).

Foucault, Michel. Discipline and Punish: The Birth of the Prison. Trans. Alan Sheridan. New York: Random House, 1977.

Fouche, Gwladys. "Mass killer Breivik says wants to create fascist party." 5 September 2014. REUTERS. <https://www.reuters.com/article/us-norway-breivik/mass-killer-breiviksays-wants-to-create-fascist-party-idUSKBN0H01NG20140905>.

Freeden, Michael, Lyman Tower Sargent and Marc Stears. "Preface." The Oxford Handbook of Political Ideologies. Ed. Michael Freeden, Lyman Tower Sargent and Marc Stears. University of Oxford: Oxford University Press, 2013. 7-9.

Freilich, Joshua, et al. "Patterns of Fatal Extreme-Right Crime in the United States." Perspectives on Terrorism (2018): 38-51.

Geuss, Raymond. The Idea of a Critical Theory: Habermas and the Frankfurt School. Cambridge: Cambridge University Press, 1981.

Hanley, Jon. "Anders Breivik's human rights violated in prison, Norway court rules." The Guardian 20 April 2016.

Hemmingby, Cato and Tore Bjørgo. The Dynamics of a Terrorist Targeting Process: Anders B. Breivik and the 22 July Attacks in Norway. New York: Palgrave Hate Studies, 2016.

Jenkins, Brian. "International Terrorism: A New Kind of Warfare." The Rand Paper Series (1974): 1-13.

Kellner, Douglas. Media Spectacle. London: Routledge, 2003.

---. "Preface: Guy Debord, Donald Trump, and the Politics of the Spectacle." The Spectacle 2.0: Reading Debord in the Context of Digital Capitalism. Ed. Marco Briziarelli and Emiliana Armano. London: University of Westminster Press, 2017. 1-13.

McCarney, Joseph. "Ideology and False Consciousness." April 2005. Marxists Internet Archive: Marx Myths and Legends. Web. 1 December 2020.

<https://www.marxists.org/archive/mccarney/2005/false-consciousness.htm\#foot-2>.

"Norway killer Anders Breivik Threatens Hunger Strike." 30 September 2015. BBC NEWS. 1 January 2019.

"Norway's Mass Killer Breivik Declared Sane." 10 April 2012. BBC NEWS. 8 January 2019.

Ravndal, Dennis. "Marit Christensen has written a book about Wenche Behring Breivik." 30 October 2013. VG: Verdens Gang. 12 December 2020.

Reitman, Janet. "U.S. Law Enforcement Failed to See the Threat of White Nationalism. Now They Don't Know How to Stop It." The New York Times Magazine 3 November 2018: 38 .

Savage, Charlie, Adam Goldman and Eric Schmitt. "U.S. Will Give Terrorist Label to White Supremacist Group for First Time." The New York Times 6 April 2020: https://www.nytimes.com/2020/04/06/us/politics/terrorist-label-white-supremacyRussian-Imperial-Movement.html. 
Seierstad, Asne. One of Us: The Story of Anders Breivik and the Massacre in Norway. New York: Macmillan, 2015.

SPLC. "Aryan Brotherhood." 4 June 2020. Southern Poverty Law Center. $<$ https://www.splcenter.org/fighting-hate/extremist-files/group/aryan-brotherhood>.

Taylor, Matthew. "Norway gunman claims he had nine-year plan to finance attacks." 25 July 2011. The Guardian. 7 January 2019.

Turrettini, Unni. Lone Wolf Killer: Anders Behring Breivik and The Threat of Terror in Plain Sight. New York: Pegasus Crime, 2015.

Vergara, Daniel. 1 October 2014. Terrorist Anders Behring Breivik has sent a letter to international media. In his letter, he describes himself as a fighter for the "survival of the Nordic race" and requires a territory for white in Norway. <https://expo.se/2014/01/breivik-vill-deportera-illojala-judar>.

"White Supremacists Embrace 'Accelerationism'." 16 April 2019. Anti-Defamation League. 12 December 2020.

Wilson, Jason. "Revealed: the true identity of the leader of an American neo-Nazi terror group." The Guardian 24 January 2020:

https://www.theguardian.com/world/2020/jan/23/revealed-the-true-identity-of-theleader-of-americas-neo-nazi-terror-group. 